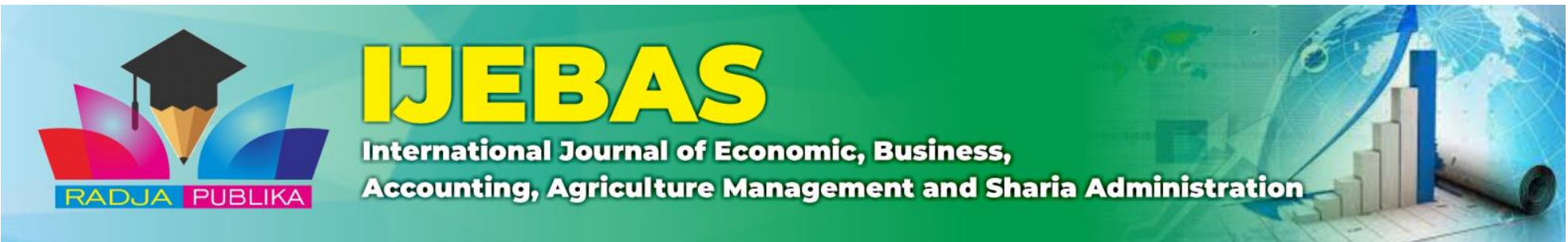

\title{
DETERMINANT MODEL OF COMPANY VALUE IN THE PROPERTY AND INFRASTRUCTURE SECTOR
}

\author{
Rezki Zurriah $^{1}$, Baihaqi Ammy², Ronni Parlindungan³ \\ ${ }^{1,2,3}$ Faculty of Economics and Business, Universitas Muhammadiyah Sumatera Utara \\ E-mail: \\ ${ }^{1)}$ rezkizurriah@umsu.ac.id*, ${ }^{2)}$ baihaqiammy@gmail.com, ${ }^{3)}$ roniparlinsipahutar@gmail.com
}

\begin{abstract}
The purpose of this study is to find out and test the effect of good corporate governance, company size, dividend policy, debt policy and profitability on the value of companies in the property and infrastructure sectors in 2008-2017 listed securities in Indonesia. This study is a causal study using secondary data. The population in the study amounted to 63 property and infrastructure companies registered with the IDX for the period 2008-2017. The sampling technique used in this study is purposive sampling where the entire population of 35 companies is used as data in this study. The analysis tool used in this study used regression analysis of panel data.
\end{abstract}

Keywords: Good Corporate Governance, Company size, Dividend Policy, Debt Policy, Profitability and Corporate Value.

\section{INTRODUCTION}

The Capital Market is a foam plate between parties who have excess funds (investors) to those who need additional funds by trading securities issued by related companies (Tandelilin, 2010). Investment activity is an activity of placing funds in one or more assets within a certain period with the hope of generating income or increasing the value of the investment. An investor in making decisions regarding investment, must always analyze and have in-depth knowledge of the performance of the company concerned. Company performance can be found through the company's internal information sourced from the company's financial statements (Hanafi and Halim, 1996).

The development of the property and infrastructure sector is currently very rapid. This is indicated by the presence of around 25 companies that have IPOs in the last five years and the property and infrastructure sector price index. Although Indonesia's economic growth slowed to its lowest level in six years in the first quarter of 2015. With the announcement of the president, Joko Widodo launched the "One million houses program" in April 2015 (www.kompas.com). This statement had an impact on the increase in stock prices in the property and infrastructure sector in 2016. 
Volume 1 No 2 (2021)

Determinant Model Of Company Value In The Property And Infrastructure Sector

DOI: $10.54443 /$ ijebas.v1i2.64

\begin{tabular}{|c|c|c|c|c|c|c|c|c|c|c|c|c|}
\hline No & Kode & Nama Perusahaan & 2008 & 2009 & 2010 & 2011 & 2012 & 2013 & 2014 & 2015 & 2016 & 2017 \\
\hline 1 & ASRI & lam Sutera Realty Tbk & 50 & 105 & 295 & 460 & 600 & 430 & 560 & 345 & 352 & 356 \\
\hline 2 & BAPA & ekasi Asri Pemula Tbk & 145 & 67 & 250 & 148 & 139 & 66 & 50 & 50 & 50 & 88 \\
\hline 3 & BIPP & Bhuawanatala Indah Permai Tbk & 50 & 50 & 50 & 50 & 101 & 90 & 95 & 88 & 90 & 73 \\
\hline 4 & BKDP & akit Darmo Property Tbk & 50 & 153 & 116 & 115 & 88 & 88 & 98 & 90 & 70 & 75 \\
\hline 5 & BKSL & Bekasi Asri Pemula Tbk & 66 & 97 & 109 & 265 & 189 & 157 & 104 & 58 & 92 & 130 \\
\hline 6 & BSDE & umi Serpong Damai Tbk & 88 & 816 & 880 & 980 & 1110 & 1290 & 1805 & 1800 & 1775 & 1700 \\
\hline 7 & COWL & velopment Tbk & 410 & 350 & 122 & 235 & 143 & 470 & 615 & 600 & 1085 & 880 \\
\hline 8 & CTRA & nt Tbk & 90 & 238 & 339 & 531 & 787 & 737 & 1228 & 1451 & 1335 & 1185 \\
\hline 9 & DART & Duta $\mathrm{A}$ & 32 & 50 & 95 & 64 & 126 & 247 & 291 & 589 & 496 & 681 \\
\hline 10 & DILD & nt Tbk & 173 & 276 & 425 & 255 & 335 & 315 & 650 & 489 & 500 & 350 \\
\hline 11 & ELTY & elopment Tbk & 72 & 1930 & 1570 & 1190 & 540 & 500 & 500 & 500 & 500 & 500 \\
\hline 12 & GMTD & Gowa Makassar T & 147 & 147 & 165 & 660 & 660 & 8300 & 6100 & 7500 & 6950 & 10175 \\
\hline 13 & GPRA & $\mathrm{a}$ Tbk & 255 & 105 & 101 & 117 & 100 & 151 & 299 & 199 & 183 & 103 \\
\hline 14 & JRPT & & 100 & 160 & 260 & 440 & 620 & 800 & 1040 & 745 & 875 & 900 \\
\hline 15 & KIJA & $\mathrm{Ka}$ & 49 & 116 & 117 & 186 & 195 & 192 & 293 & 245 & 290 & 286 \\
\hline 16 & LCGP & Tbk & 50 & 50 & 50 & 59 & 170 & 285 & 600 & 620 & 135 & 80 \\
\hline 17 & LPCK & & 190 & 225 & 395 & 1790 & 3225 & 4875 & 10400 & 7250 & 5050 & 3140 \\
\hline 18 & LPKR & Lipp & 760 & 485 & 680 & 660 & 1000 & 910 & 1020 & 1035 & 720 & 488 \\
\hline 19 & MDLN & Moder & 25 & 63 & 123 & 120 & 305 & 390 & 520 & 467 & 342 & 294 \\
\hline 20 & MKPI & $\mathrm{a}$ Tbk & 0 & 2750 & 2800 & 2900 & 3900 & 9500 & 15300 & 16875 & 25750 & 36500 \\
\hline 21 & OMRE & Indon & 475 & 400 & 170 & 265 & 335 & & 340 & 300 & 216 & 880 \\
\hline 22 & PLIN & Plaza Ind & 2400 & 2500 & 1990 & 1550 & 1629 & 1920 & 3750 & 4000 & 4850 & 3550 \\
\hline 23 & PUDP & Pudjiati Pr & 68 & 218 & 294 & 414 & 490 & 480 & 450 & 420 & 380 & 450 \\
\hline 24 & PWON & & 98 & 130 & 203 & 188 & 225 & 270 & 515 & 496 & 565 & 685 \\
\hline 25 & RBMS & Ristia Binta & 96 & 48 & 52 & 55 & 92 & 58 & 56 & 40 & 55 & 153 \\
\hline 26 & RODA & Pikko Land Development Tbk & 66 & 54 & 50 & 225 & 350 & 450 & 463 & 595 & 390 & 170 \\
\hline 27 & SCBD & Danayasa Arthatama Tbk & 630 & 630 & 500 & 500 & 830 & 2700 & 2000 & 1695 & 1650 & 2700 \\
\hline 28 & SMDM & Suryamas Dutamakmur Tbk & 110 & 83 & 101 & 130 & 191 & 190 & 124 & 95 & 76 & 106 \\
\hline 29 & SMRA & Summarecon Agung Tbk & 83 & 300 & 545 & 620 & 950 & 780 & 1520 & 1650 & 1325 & 945 \\
\hline 30 & $\mathrm{ADHI}$ & & 240 & 348 & 772 & 492 & 1493 & 1281 & 2963 & 2140 & 2080 & 1885 \\
\hline 31 & DGIK & Nusa Konstruksi Enjinring Tbk & 50 & 87 & 146 & 89 & 144 & 150 & 179 & 85 & 55 & 58 \\
\hline 32 & PTPP & Pembangunan Perumahan (persero) & 0 & 0 & 760 & 461 & 789 & 1103 & 3397 & 3683 & 3810 & 2640 \\
\hline 33 & SSIA & Surya emesta Internisa Tbk & 100 & 70 & 233 & 720 & 1080 & 560 & 1070 & 715 & 434 & 515 \\
\hline 34 & TOTL & Total Bangunan Persada Tbk & 71 & 150 & 255 & 285 & 900 & 500 & 1120 & 615 & 765 & 660 \\
\hline 35 & WIKA & Wijaya Karya (persero) Tbk & 204 & 301 & 630 & 565 & 1370 & 1463 & 3408 & 2445 & 2360 & 1550 \\
\hline
\end{tabular}

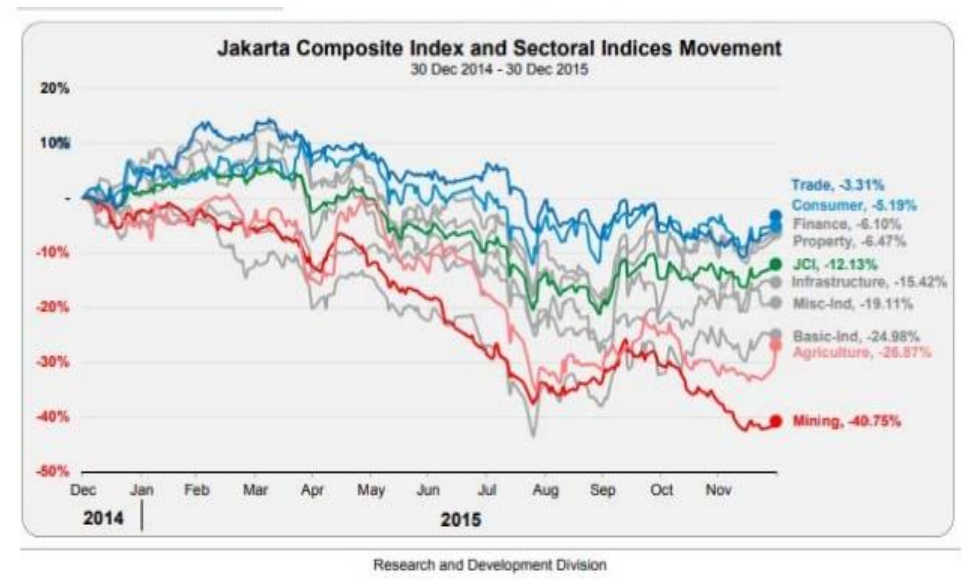

Figure 1.1 Development of sectoral stock prices on the IDX

Table 1.1 describes property and infrastructure companies listed on the Indonesia Stock Exchange (IDX). The number of property and real estate companies listed on the IDX is 63 companies, but only 35 companies publish their financial reports regularly every year. Table 1.1 shows that the share prices of property and infrastructure companies in 2008-2017 experienced price fluctuations every year. In table 1.1 in 2017 the highest share price level was obtained by PT 
Metropolitan Kentjana Tbk with a share price of Rp 36,500 and the lowest price obtained by PT Nusa Konstruksi Enjinring Tbk with a share price of Rp 58.

In Figure 1.1, it can be seen that in 2015 the property sector decreased by $-6.47 \%$ and the infrastructure sector decreased by $-15.42 \%$. The share price is the price that investors will pay as a form of ownership. The higher the value of the company, the more investors are willing to pay for shares. In the growing business world, every company strives to always be dynamic in following market demands and external demands. Competition in the property and infrastructure industry makes every company increase its performance so that goals can be achieved. The increase in stock prices means that the value of the company also increases.

The information presented in the financial statements is sufficient to describe the development of the company and its achievements. If the company's financial performance shows good prospects, shareholders or potential investors will be interested in buying shares which will affect stock prices (tcvetkov et al, 2015).

A company management strategy where company owners must dare to take steps to hand over the management of their company to more skilled and professional parties or personnel. Parties who are considered experts and professionals in the company are often called agents or management. Management is expected to be able to take the right action or decision so that the company can survive with high profits and so that the prosperity of the owner of the company is maximized and the company will be viewed favorably by potential investors.

According to agency theory, the separation of ownership and management can lead to agency conflicts (Rachmawati and Triatmoko, 2006). Agency conflict causes a decrease in the value of the company. The decrease in the value of the company will affect the wealth of the shareholders, so that the shareholders will take action to supervise the behavior of management. In this case, managerial ownership is seen as an appropriate control mechanism to reduce the conflict. Managerial ownership is a situation where the manager owns the company's shares or in other words the manager is also a shareholder of the company (Christiawan and Tarigan, 2007).

Jensen and Meckling (1976) stated that giving trust by company owners to managers is considered a form of separation of decision making functions. Where this form of separation will lead to a conflict between the owner of the company as the principal and the manager as the agent. In fact, managers will prioritize the interests of achieving high levels of salary and compensation rather than trying to maximize the wealth of the owners of the company. One of the manager's actions is to charge costs for the benefit of managers outside the business to maximize the prosperity of the owner of the company so that it will have the impact of decreasing dividends that will be obtained by the company.

Based on agency theory, the existence of a high-quality good corporate governance (GCG) mechanism must be balanced against agency costs in the relationship between principals (shareholders) and their agents (managers) (Jensen and Meckiling, 1976). High quality GCG mechanisms are highly valued by the stock market. An investor who will decide and invest funds needs to do a careful and thorough assessment of the issuer. investors must believe that the information received is correct (Mahendra, 2011).

The concept of corporate governance emerged when two legal experts, namely Adolf August Berle and Gardiner C. Means published a monograph entitled "The Modern Corporation and Private Property" followed by Eugene Fama and Micheal Jense in the article "Separation of owneship and Corporate of owner Ship". and control" with the principal agency theory. The issue of corporate governance is growing when several economic events occur. Asian financial crisis in 1997. Followed by the collapse of large companies such as Enron and World Com in 2002, as well as the issue of the subprime mortgage crisis in the United States in 2008. These events made the world aware of the importance of implementing Good Corporate Governance.

In Indonesia, the issue of good corporate governance surfaced after Indonesia experienced a prolonged crisis since 1998. Since then, the government and investors have paid more attention to corporate governance practices. It can be understood that the existence of global competition is not 
competition between countries, but between corporations in these countries. So winning or losing, recovering or continuing to decline in the economy of a country depends on their respective corporations. This understanding opens up insight that our corporation has not been managed properly (Moeljono, 2005 in Kaihatu 2006). GCG is needed to encourage the creation of an efficient, transparent and consistent market with laws and regulations. GCG implementation needs to be supported by three interconnected pillars,

The study of water house cooper prices published in the report on institute survey (2002) places Indonesia at the bottom along with China and India with a score of $1.92 \%$ for transparency and openness. The report on GCG by the Asian Corporate Governance Association (2003) places Indonesia at the bottom with a score of 1.5 for law enforcement issues, 2.5 for institutional mechanisms and corporate governance culture with a total of 3.2 (Kaihatu, 2006). This is due to the constraints faced by companies in Indonesia, namely internal constraints (commitment of the leadership and members of the company, the level of understanding of the leadership and members of the company about the principles of good corporate governance, effective internal control items and trapped in formalities) and constraints external (legal instruments, rules and enforcement). According to the Asian Corporate Governance Association, Indonesia is ranked 11th out of 11 Asian countries with 38 points (CSLA, 2016).

In the field of economics and finance, the company's ownership structure is one of the measuring tools to determine the performance of a company (Cornett et al, 2005). The company has managerial ownership and public ownership. Shleifer and Vishny (1997) explain that managers control the company and agency problems that occur between shareholders and managers. Basically, shareholders who are users and beneficiaries of financial statements will assess the performance of management as the party responsible for running shareholder funds (Oktavia and Desmawati, 2008). With the increase in the level of public ownership, it is able to create greater oversight so that opportunistic behavior of managers is hindered.

Company size is one of the variables considered in determining the value of a company. Company size is a reflection of the total assets owned by a company. Companies themselves are categorized into two types, namely small-scale companies and large-scale companies. Company size is a reflection of the total assets owned by the company. The larger the size of the company, it means that the assets owned by the company are even greater and the funds needed by the company to maintain its operational activities are increasing and can optimize the value of the company. In this case, PT Lippo Cikarang Tbk. Total assets in 2014 amounted to Rp. 4,390,498,820,383 with a 2015 share value of Rp 10,400. In 2016 there was an increase in total assets of Rp. 12,378,227,000. 000 with a decrease in share price to Rp 3,140. it can be seen from the data above that the increase in assets cannot reflect the increase in stock prices.

The stock price for a company that experiences constant growth shows that higher dividend payments tend to increase the value of the company. However, higher dividend payments will also reduce the company's growth rate and will further reduce the value of shares. Thus, delaying the payment of dividends to shareholders for profitable investment purposes (if the return is greater than the cost of capital) will increase the share price (in a perfect capital market). In an imperfect capital market, dividend payments to increase the value of shares will be very detrimental because they have to pay fluctuation fees.

Debt policy that describes the composition of financing in the company's financial structure. The larger the company will require the greater the capital, which is usually met by management by using external sources of funds in other words debt. In a certain composition, debt will increase the productivity of the company which will automatically increase the value of the company. But if the composition becomes excessive then what will happen is a decrease in the value of the company. Even if the amount of long-term debt is there with the amount of equity, it can be ascertained a deficit. Therefore, management must be careful in determining its debt policy in order to increase the value of the company. 


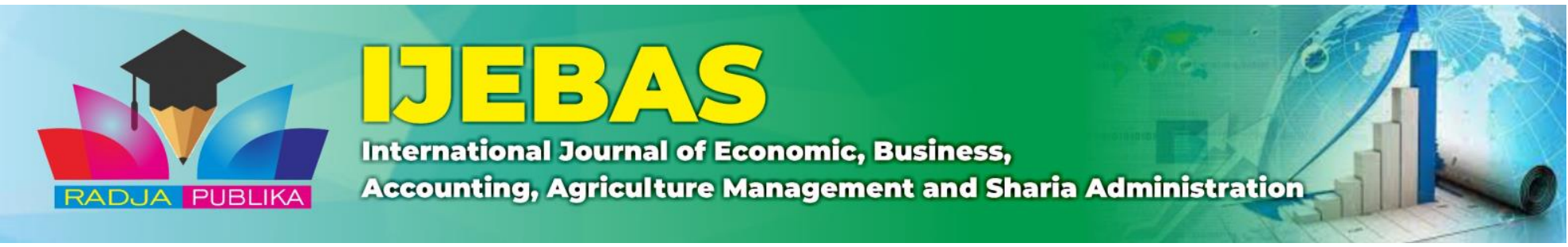

It can be seen from PT Lippo Cikarang Tbk that the total debt in 2014 was 1,712,352,407,686 with a share price of Rp. 10,400 in 2017 total debt was Rp.4,657,491,000,000 with a share price of 3140. From this we can see that the increase in debt cannot reflect the increase in share prices. The company to be able to carry out its operating activities, must be in a profitable condition. Without profit it will be difficult for companies to attract capital from outside. Money companies that have a high level of profitability will be interested in their shares by investors. So that it can affect the value of the company.

There is a significant and strong relationship between firm value and financial performance. Financial performance is expected to predict the value of the company in the future. However, there is an inconsistent effect of financial ratios on firm value. Namely good corporate governance, capital structure, debt policy, dividend policy and profitability. Some of these factors have an inconsistent relationship and influence on firm value.

\section{IMPLEMENTATION METHOD}

This study uses a quantitative approach, namely by testing the associative relationship of measurable (parametric) research variables. This research is a causal research (Causal Effect) that is research that is included to reveal the cause and effect relationship between related variables (Sularso, 2004:13). The purpose of causal research is to investigate possible cause-and-effect relationships in a way based on observations of existing effects and look for factors that may have occurred through certain data. This research is conducted by building a hypothesis first which will then be measured by statistical tools. This study uses the observation method of panel data, which is a combination of cross section data and time series data,

Table 1 Research Criteria

\begin{tabular}{|c|c|c|}
\hline No & Sample criteria & $\begin{array}{l}\text { Number of } \\
\text { companies }\end{array}$ \\
\hline 1. & $\begin{array}{l}\text { Property and infrastructure companies } \\
\text { listed on the Indonesian stock exchange } \\
2011-2016\end{array}$ & 63 \\
\hline 2. & Companies that do not meet the criteria & $(28)$ \\
\hline & Sample companies & 35 \\
\hline & Number of observations ( $35 \times 10)$ & 350 \\
\hline
\end{tabular}

The data used by the researcher is secondary data, namely the company's annual reports on all companies that are the research sample. The data sources were obtained from the Indonesia Stock Exchange (www.idx.co.id) and the websites of each sample company. Research data is presented in panel data (between time) and cross section (between companies).

\section{RESULTS AND DISCUSSION}

\subsection{Research result}

This study examines the variables that affect firm value. The variables used in this study are good corporate governance, company size, dividend policy, debt policy and profitability.

\subsubsection{Classic assumption test}

The classical assumption test used in this study includes normality test, multicollinearity test, autocorrelation test, and heteroscedasticity test.

\subsubsection{Normality Test}

In this study, the normality test of the residuals used the Jarque-Bera (JB) test. In this study, the significance level used was. The basis for making decisions is to look at the probability numbers from the JB statistics, with the following conditions. $\alpha=0,05$ 
- If the probability value is 0.05 , then the assumption of normality is met. $p \geq$

- If probability $<0.05$, then the assumption of normality is not met.

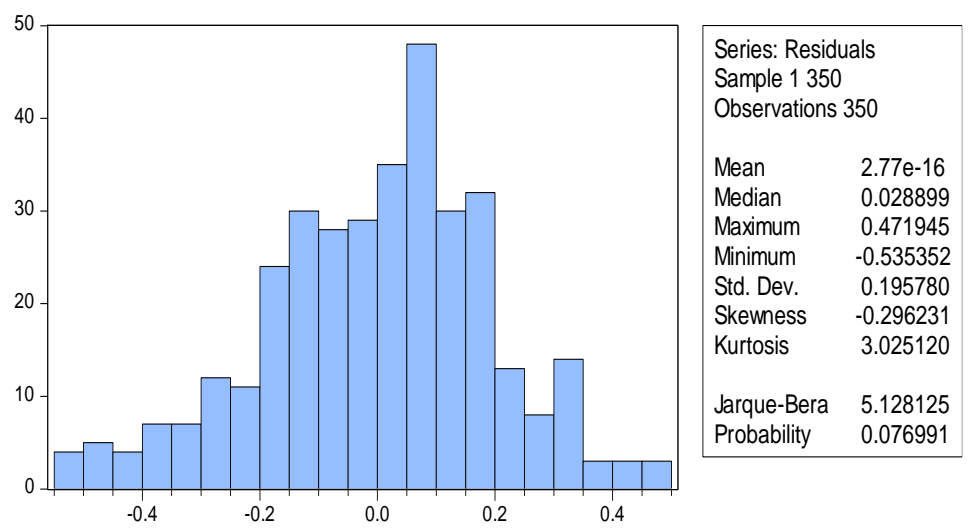

Figure 2 Normality Test with Jarque-Bera . Test

Note that based on Figure 5.1, it is known that the probability value of the JB statistic is 0.076991 . Because the probability value, which is 0.076991 , is greater than the significance level, which is 0.05 . This means that the assumption of normality is met.p

\subsubsection{Multicollinearity Test}

In this study, the symptoms of multicollinearity can be seen from the correlation value between the variables contained in the correlation matrix. Ghozali (2013) states that if there is a fairly high correlation between independent variables, which is above 0.9, then this is an indication of multicollinearity. The results of the multicollinearity test are presented in the following table:

Table 2 Multicollinearity Test with Correlation Matrix

\begin{tabular}{|c|c|c|c|c|c|}
\hline \multicolumn{2}{|c|}{$\mathrm{X} 1$} & & & & 55 \\
\hline $\mathrm{X} 1$ & 1.0000000 & -0.219852 & 0.053176 & -0.039180 & 0.090283 \\
\hline $\mathrm{X} 2$ & -0.219852 & 1.0000000 & -0.033133 & 0.043505 & 0.088289 \\
\hline $\mathrm{X} 3$ & 0.053176 & -0.033133 & 1.0000000 & -0.005549 & 0.024722 \\
\hline $\mathrm{X} 4$ & -0.039180 & 0.043505 & -0.005549 & 1.0000000 & 0.362197 \\
\hline $\mathrm{X5}$ & 0.090283 & 0.088289 & 0.024722 & 0.362197 & 1.0000000 \\
\hline
\end{tabular}

Based on Table 5.2 the results of the multicollinearity test, it can be concluded that there are no symptoms of multicollinearity between the independent variables. This is because the correlation value between independent variables is not more than 0.9 (Ghozali, 2013: 105).

\subsubsection{Heteroscedasticity Test}

Detection of the presence or absence of heteroscedasticity can be done with the Breusch-Pagan test (Gujarati, 2003, Gio and Elly, 2015). The following are the results of the Breusch-Pagan test.

Table 3 Heteroscedasticity Test (Breusch-Pagan Test) Heteroskedasticity Test: Breusch-Pagan-Godfrey

\begin{tabular}{llll}
\hline \hline F-statistics & 1.642650 & Prob. F(5,344) & 0.1481 \\
Obs*R-squared & 8.161641 & Prob. Chi-Square(5) & 0.1475 \\
\hline
\end{tabular}

It is known that the Prob Obs*R-Squared value is $0.1475>0.05$, which means that there is no heteroscedasticity.

\subsubsection{Autocorrelation Test}




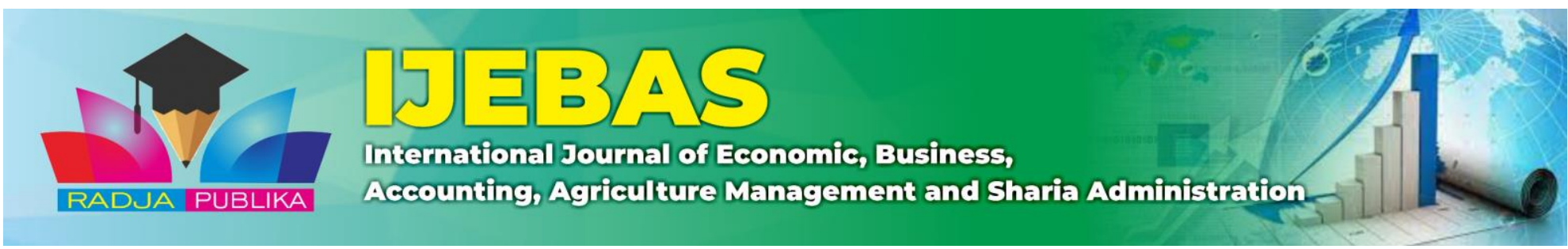

The autocorrelation test aims to see whether there is a correlation between a period $t$ and the previous period. Autocorrelation generally occurs in time series data. If the DW value lies between du and $(4-\mathrm{du})$ or du $<$ with DW < with $(4-\mathrm{du})$. It means that it is free from autocorrelation. If the DW value is less than $\mathrm{dL}$ or DW is greater than $(4-\mathrm{dL})$ it means that there is autocorrelation.

Table 4 Autocorrelation Test with Durbin-Watson Test

\begin{tabular}{lclc}
\hline Likelihood logs & 74.63953 & $\begin{array}{l}\text { Hannan Quinn } \\
\text { Criter. }\end{array}$ & -0.365901 \\
& & Durbin-Watson stat & 1.043589 \\
\hline
\end{tabular}

Based on the table, the value of the Durbin-Watson statistic is 1.043589 . Note that since the Durbin-Watson statistic is between 1 and 3, i.e. $1<1.043589<3$, the non-autocorrelation assumption is met. In other words, there is no high autocorrelation symptom in the residuals.

\subsubsection{Selection of Estimation Method}

\subsubsection{Determination of Estimated Model between Common Effect Model (CEM) and Fixed Effect Model (FEM) with Chow Test}

To determine whether the estimation model is CEM or FEM in forming a regression model, the Chow test is used. The hypothesis being tested is as follows.

- $H_{0}$ : The FEM model is no better than the CEM model.

- $H_{1}$ : FEM model is better than CEM model

The following are the results based on the Chow test using Eviews 7.

Table 5 Results of the Chow Test

Redundant Fixed Effects Tests

Pool: DPANEL

Test cross-section fixed effects

\begin{tabular}{lrrr}
\hline \hline \multicolumn{1}{c}{ Effects Test } & Statistics & df & Prob. \\
\hline \hline Cross-section F & 8.946200 & $(34,310)$ & 0.0000 \\
Cross-section Chi-square & 239.295259 & 34 & 0.0000 \\
\hline
\end{tabular}

The decision-making rules for the hypothesis are as follows.

If the probability value:

- Cross-section Chi-square $<0.05$, then it is rejected and accepted $H_{0} H_{1}$

- Cross-section Chi-square $\geq 0.05$, then accepted and rejected. $H_{0} H_{1}$

Based on the results of the Chow test in Table 5, it is known that the probability value is 0.0000 . Because the probability value is $0.0000<0.05$, the estimation model used is the fixed effect model (FEM).

\subsubsection{Determination of Estimated Model between Common Effect Model (CEM) and Fixed Effect Model (FEM) with Chow Test}

To determine whether the estimation model is FEM or REM in forming a regression model, the Hausman test is used. The hypothesis being tested is as follows.

- $H_{0}$ : The FEM model is not better than the REM model (Prob. $>0.05$ ).

- $H_{1}$ : FEM model is better than REM model (Prob. < 0.05)

Here are the results based on the Hausman test using Eviews: 
Determinant Model Of Company Value In The Property And Infrastructure Sector DOI: $10.54443 /$ ijebas.v1i2.64

Table 6 Results from Hausman Uji Test Correlated Random Effects - Hausman Test Pool: DPANEL Test cross-section random effects

\begin{tabular}{rlrr}
\hline \hline Test Summary & $\begin{array}{c}\text { Chi-Sq. } \\
\text { Statistics }\end{array}$ & Chi-Sq. df & Prob. \\
\hline \hline Cross-section random & 15.004945 & 5 & $\mathbf{0 . 0 1 0 3}$ \\
\hline
\end{tabular}

The decision-making rules for the hypothesis are as follows.

If the probability value:

- Random cross-section $<0.05$, then it is rejected and accepted. $H_{0} H_{1}$

- Random cross-section $\geq 0.05$, then accepted and rejected. $H_{0} H_{1}$

Based on the results of the Hausman test in Table 5.6, it is known that the probability value is 0.0103 . Because the probability value is $0.0103<0.05$, the estimation model used is the fixed effect model (FEM).

\subsubsection{Hypothesis Testing}

In testing the hypothesis, the coefficient of determination analysis will be carried out, simultaneous effect testing ( $F$ test), and partial effect testing ( $t$ test). Statistical values of the coefficient of determination, $\mathrm{F}$ test, and $\mathrm{t}$ test are presented in the following table:

Table 7 Statistical values of the Coefficient of Determination, F-Test, and tTest Dependent Variable: Y?

Method: Pooled Least Squares

Date: 11/07/18 Time: 05:47

Sample: 20082017

Included observations: 10

Cross-sections included: 35

Total pool (balanced) observations: 350

\begin{tabular}{lllcl}
\hline \hline Variable & Coefficient & Std. Error & t-Statistic & Prob. \\
\hline \hline X1? & -0.137509 & 0.054303 & -2.532255 & 0.0118 \\
X2? & -0.000904 & 0.009857 & -0.091706 & 0.9270 \\
X3? & -0.026250 & 0.013010 & -2.017763 & 0.0445 \\
X4? & 0.000260 & 0.000799 & 0.325346 & 0.7451 \\
X5? & 0.000198 & $6.87 \mathrm{E}-05$ & 2.874220 & 0.0043 \\
C & 0.330440 & 0.279795 & 1.181007 & 0.2385 \\
\hline \hline R-squared & 0.571637 & Mean dependent var & 0.239446 & \\
Adjusted R- & & & & \\
squared & 0.517746 & SD dependent var & 0.212519 & \\
SE of regression & 0.147583 & Akaike info criterion & -0.881641 & \\
Sum squared resid & 6.752034 & Schwarz criterion & -0.440734 & \\
Likelihood logs & 194.2872 & Hannan Quinn Criter. & -0.706144 & \\
F-statistics & 10.60731 & Durbin-Watson stat & 1.673425 & \\
Prob(F-statistic) & 0.000000 & & & \\
\hline \hline
\end{tabular}

\subsubsection{Coefficient of Determination Analysis}


Based on Table 7, it is known that the coefficient of determination (Adjusted R-squared) is . This value can be interpreted GCG, company size, dividend policy, debt policy, profitability are able to influence / explain the value of the company simultaneously or jointly by $51.77 \%$, the remaining $48.23 \%$ is influenced by other factors. $R^{2}=0,5177$.

\subsubsection{Simultaneous Effect Significance Test (F Test)}

The test aims to test the effect of the independent variables together or simultaneously on the dependent variable. Based on Table 5.7, it is known that the value of Prob. (F-statistics), which is 0.00000 .05 , it can be concluded that all independent variables, namely GCG, firm size, dividend policy, debt policy and profitability simultaneously, have a significant effect on the firm value variable.F $<$.

\subsubsection{Panel Data Regression Equation and Partial Effect Significance Test (t Test)}

Based on Table 5.7, the panel data regression equation is obtained as follows.

$$
Y=0,3304-0,1375 X_{1}-0,0009 X_{2}-0,026250 X_{3}+0,0002 X_{4}+0,0001 X_{5}
$$

\section{Based on Table 7, it is known:}

1. It is known that the regression coefficient value of the GCG variable is -0.1375 , which is negative. This means that GCG has a negative effect on firm value. It is known that the Prob value is 0.0118 , which is $<0.05$ significance level, then GCG has a significant effect on firm value.

2. It is known that the regression coefficient value of the firm size variable is -0.0009 , which is negative. This means that the size of the company has a negative effect on the value of the company. It is known that the Prob value is 0.9270 , which is > the significance level of 0.05 , then the size of the company has no significant effect on the value of the company.

3. It is known that the regression coefficient value of the dividend policy variable is -0.0262 , which is negative. This means that dividend policy has a negative effect on firm value. It is known that the Prob value is 0.0445 , which is $<0.05$ significance level, then the dividend policy has a significant effect on firm value.

4. It is known that the regression coefficient value of the debt policy variable is 0.0002 , which is positive. This means that debt policy has a positive effect on firm value. It is known that the Prob value is 0.7451 , ie $>$ the significance level of 0.05 , then the debt policy has no significant effect on firm value.

5. It is known that the regression coefficient value of the profitability variable is 0.000190 , which is positive. This means that profitability has a positive effect on firm value. It is known that the Prob value is 0.0043 , which is $<0.05$ significance level, then profitability has a significant effect on firm value.

\subsection{Discussion}

The results of hypothesis testing can be concluded that the variables of GCG, firm size, dividend policy, debt policy and profitability simultaneously have a significant effect on the firm value variable. The good corporate governance variable has a significant negative effect on the firm value variable. The firm size variable has a negative and insignificant effect on firm value. And the dividend policy variable has a significant negative effect on firm value. The debt policy has a positive and insignificant effect on firm value. While profitability has a significant positive effect on firm value.

\subsubsection{Partial Effect of Firm Size on Corporate Social Responsibility Disclosure}


The test results of good corporate which are projected through company ownership on firm value have a significant negative effect on firm value. It is negative as seen from the regression coefficient value of -0.1375 and the significant value is 0.0118 which is smaller than 0.005 . Negative effect indicates that institutional ownership is not in line with firm value. Where the increasing institutional ownership will reduce the value of the company, and vice versa the decreasing institutional ownership will increase the value of the company. Significant effect shows that institutional ownership has an important influence on firm value.

The agency theory explains that supervision is carried out by institutional ownership which will monitor agents for the purpose of increasing firm value. And in this case it shows that institutional ownership does not supervise management but participates in controlling the company so that it tends to act in their own interests and sacrifices the interests of minority ownership. Because of this tendency, there is an imbalance in the company's policy determination so that in the end it only benefits the majority shareholder.

This is not in line with research by Imelda (2016) which states that institutional ownership has a positive and insignificant effect. From this research, institutional ownership has a significant negative effect on firm value. These results do not support the theory that institutional ownership increases the proportion of supervision over company management which will increase firm value.

\subsubsection{Partial Influence of Board of Commissioners Size on Corporate Social Responsibility Disclosure}

The test results of firm size on firm value are negative and not significant for firm value. It is known that the regression coefficient value of the firm size variable is -0.0009 , which is negative. This means that the size of the company has a negative effect on the value of the company. It is known that the Prob value is 0.9270 , which is > the significance level of 0.05 , then the size of the company has no significant effect on the value of the company. Negative effect indicates that the size of the company is not in line with the value of the company. Where the increasing size of the company will reduce the value of the company, and vice versa, the decreasing size of the company will increase the value of the company. The insignificant effect indicates that firm size has no significant effect on firm value.

From this research, firm size has a negative and insignificant effect on firm value. from the management side If the company has large total assets, the management is more flexible in using the assets in the company. But the freedom this management has is outweighed by the concern the owners have over their assets. A large number of assets will reduce the value of the company if it is assessed from the side of the company owner. Therefore, the size of the company is not significant to the value of the company.

This research is in line with research conducted by Dewi and Wirajaya (2013) which states that firm size has no significant effect on firm value. This is not in line with the research of Wahyuni et al (2013), Hermuningsih (2012), Wihaidjo (2014), which stated that firm size has a positive and significant effect on firm value.

\subsubsection{The Effect of Dividend Policy Effect on Firm Value}

The results of testing the dividend policy on firm value are significant negative on firm value. It is known that the regression coefficient of the dividend policy variable is -0.0262 , this means that the dividend policy has a negative effect on firm value. It is known that the Prob value is 0.0445 , which is $<0.05$ significance level, then the dividend policy has a significant effect on firm value. Negative influence shows the company's dividend policy is not in line with the value of the company. Where is increasing. Dividend policy will reduce the value of the company, and vice versa if the dividend policy decreases, it will increase the value of the company. Significant effect shows that dividend policy has an important effect on firm value.

This study is in line with the theory put forward by Miller and Modligiani which states that dividend policy does not affect firm value because according to them the dividend payout ratio is 
only a detail and does not affect the welfare of shareholders. The increase in the value of dividends is not always followed by an increase in the value of the company and this study is not in line with the research conducted (Mardiayati, Putrid, Ahmad 2005) dividend policy has a positive but not significant effect on firm value.

\subsubsection{The Effect of Debt Policy on Firm Value}

The results of the debt policy test on firm value Significantly positive on firm value. It is known that the regression coefficient of the debt policy variable is 0.0002 , this means that debt policy has a positive effect on firm value. It is known that the Prob value is 00.7451 , which is $>$ the significance level of 0.05 , so debt policy has no significant effect on firm value. Positive influence shows that debt policy is in line with firm value. Where the increasing debt policy will increase the value of the company, and vice versa the decreasing debt policy will reduce the value of the company. Significant effect indicates that debt policy has an insignificant effect on firm value.

This study states that the funding policy has a positive and insignificant effect on firm value. Funding decisions include determining external and internal funding sources. External funding sources can be obtained from debt and new equity, while internal funding sources are obtained from retained earnings. The better the funding decisions made by the company, the more positive it will be for increasing the value of the company. This positive result indicates that the increase in debt is interpreted by outsiders about the company's ability to pay obligations in the future or the existence of low business risk, this is not necessarily responded by the market. Increasing funding through debt is one alternative to reduce agency costs.

This study is not in line with research by Imelda (2015) which states that debt policy has a negative and significant effect on firm value. And in line with research by Wijaya and Wibaya (2006) which states that funding decisions have a positive and significant effect on firm value.

\subsubsection{The Influence of Profitability on Firm Value}

Profitability test results on firm value Significantly positive on firm value. It is known that the regression coefficient value of the debt policy variable is 0.000190 , this means that profitability has a positive effect on firm value. It is known that the Prob value is 0.0043 , which is $<0.05$ significance level, then profitability has a significant effect on firm value. Positive influence shows the company's profitability is in line with company value. Where the increasing profitability will increase the value of the company, and vice versa the decreasing profitability will reduce the value of the company. Significant effect shows that profitability has an important effect on firm value.

The results of this study are in line with the research conducted by Imelda (2015) and Wahyuni et al (2013) which stated that profitability had a positive and significant effect on firm value. From this research, it is found that high profits will provide an indication of good company prospects so that it can trigger investors to participate in increasing demand for shares. The increasing demand for shares will cause the value of the company to increase.

\section{CONCLUSION}

From the research conducted, it can be concluded as follows:

1. Institutional ownership has a negative and significant effect on firm value.

2. Firm size has a negative and insignificant effect on firm value

3. Dividend policy has a negative and significant effect on firm value

4. Debt policy has a positive and insignificant effect on firm value

5. Profitability has a positive and significant effect on firm value

6. Good Corporate Governance, Company Size, Dividend Policy, Debt Policy and Profitability simultaneously, have a significant effect on the firm value variable.

\section{REFERENCES}


Bathala., CT, Moon., KP, Rao., RP, (1994) Managerial Ownership, Debt Policy, and The Impact of Institutional Holding : An Agency Perspective.FinancialManagement, Vol. 23, No.3

Benhart, S. W., Rosenstein S. (1998 ). Board Composition, Managerial Ownership, and Firm Performance: An Empirical Analysis. Financial Review, 33, pp. 1-16.

Brigham, Eugene.F dan Joel.F Houston. (2008). Fundamental of Financial Management. Twelfth Edition. United States of America : South-Western Cengage Learning.

Bursa Efek Indonesia.Indonesian Capital Market Directory. www.idx.co.id.2008-2017. Jakarta.

Christiawan,Yulius jogi dan Tarigan,Josua (2007). Kepemilikan Manajerial: kebijakan Hutang, Kinerja dan Nilai Perusahaan, Jurna Akuntansi dan Keuangan Vol 9 No.1

Cornett, Marcia Millon,Guo,Lin, Khaksari, Shahriar,Tehranian, Hasan (2005) The Impact of State ownership on performance differences in privately-owned versus state-owned bank; An international comparison. Journal Finance Intermediation 19 74-94.

Daniri Mas Ahmad ( 2005), Good Corporate Governance : Konsep dan Penerapannya di Indonesia. Ray Indonesia, Jakarta,.

Darmawati, Deni.; Khomsiyah dan Rika Gelar Rahayu (2005), "Hubungan Corporate governance dan Kinerja Perusahaan”, Jurnal Riset Akuntansi Indonesia, Vol. 8, No. 1, Januari.

Eisenhardt K.M (1989). Agency Theory: an Assessment and Review, Academy of Management Revie, Vol 14

Frederick, Carlson dan Bathala E.K. (1997). "Influence Analysis Liquidity Ratios, Leverage, Activity and Profitability to Return Shares", Journal of Business,Hal. 1-54.

Forum for Corporate Governance in Indonesia, Peranan Dewan Komisaris dan Komite Audit dalam Pelaksanaan Corporate Governance (Tata Kelola Perusahaan)

Ghozali, Imam (2013) Aplikasi Analisis Multivariate Denᄀgan Program SPSS. Semarang. Badan Penerbit Undip.

Hanafi, Mahmud M. dan Abdul Halim (20030 Analisis Laporan Keuangan. Yogyakarta : AMPYKPN

Herawaty, Vinola (2008) Peran Praktek Corporate Governance sebagai Moderating Variable dari Pengaruh Earnings Management Terhadap Nilai Perusahaan. Jurnal Akuntansi dan Keuangan, 10 (2).

Horne, R, dan Wachowicz, Steve., (2005) Manajemen Keuangan Edisi Kesembilan. Penerbit Mediakom, Yogyakarta.

Ismiyanti, Fitri dan Mamduh, M. Hanafi. (2004). "Struktur Kepemilikan, Risiko, dan Kebijakan Keuangan: Analisis Persamaan Simultan". Jurnal Ekonomi dan Bisnis Indonesia, Vol 19, No 2, 176-196.

Mahendra, Alfredo (2011) Pengaruh Kinerja Keuangan Terhadap Nilai Perusahaan (Kebijakan Deviden Sebagai Variabel Moderating) pada Perusahaan Manufaktur DI Bursa Efek Indonesia. Thesis. Denpasar : Universitas Udayana.

Jensen dan willian H Meckling. (1976). Theory of firm; Managerial Behavior, AgencyCost and Ownership Stricture. Journal of Financial Economics 3:305-360.

Jogi, Yulius.C dan Josua Tarigan. (2007). "Kepemilikan Manajerial : Kebijakan Hutang, Kinerja dan Nilai Perusahaan". Jurnal Akuntansi dan Keuangan, Volume 9, No.1, h. 3-5.

Kaihatu, Thomas. (2006). Good corporate governance dan penerapannya di Indonesia. Jurnal Manajemen dan Kewirausahaan Vol. 8 No 1, p.1-9

Kim, O., Verrecchia, R., (1994) Market liquidity and volume around earnings announcements .Journal of Accounting and Economics 17 (1/2), 41-67.

Mamduh M. Hanafi dan Abdul Halim, 2005, Analisa Laporan Keuangan

Modigliani, Fraco \& Miller. Merton H ( 1958) The Cost of Capital, Corporation and The Teory of investment. The America Economic Review vol 48 no 3 PP 261-297.

Marihot Nasution dan Doddy Setiawan, 2007, "Pengaruh Corporate Governance Terhadap Manajemen Laba di Industri Perbankan Indonesia". Makalah disampaikan pada Simposium Nasional Akuntansi X. Ikatan Akuntasi Indonesia. 
Myers, S. C. and Nicholas, S. M. (1984). Corporate financing decisions when firms have invest-ment information that investors do not. Journal of Financial Economics, 13(2), 187-220.

Marihot Nasution dan Doddy Setiawan (2007), "Pengaruh Corporate Governance Terhadap Manajemen Laba di Industri Perbankan Indonesia". Makalah disampaikan pada Simposium Nasional Akuntansi X. Ikatan Akuntasi Indonesia.

Praktik Ear-nings Management pada Perusahaan Ter-daftar di PT Bursa EfekIndonesia. Jurnal Manajemen Dan Kewirausahaan, 11(1), 1-10.

Midiastuty, Pratana dan Machfoedz, Mas'udz, (2003) "Analisis HubunganMekanisme Corporate Governance dan Indikasi Manajemen Laba”,Simposium Nasional Akuntansi VI.

Mahendra, Alfredo (2011) Pengaruh Kinerja Keuangan Terhadap Nilai Perusahaan (Kebijakan Deviden Sebagai Variabel Moderating) pada PerusahaanManufaktur DI Bursa Efek Indonesia. Thesis. Denpasar : Universitas Udayana.

Mutamimah. (2003) “Analisis Struktur Modal Pada Perusahaan-Perusahaan NonFinansial Yang Go Public Di Pasar Modal Indonesia". Jurnal Bisnis Strategi. Vol. 11 Juli. Pp 71-60

Masdupi, Erni. (2005) Analisis Dampak Struktur Kepemilikan pada Kebijakan Hutang dalam Mengentrol Konflik Keagenan, Jurnal ekonomi dan Bisnis Indonesia, Vol 20, No. 1, Januari, Hlm 57-69

Moeljono, Djokosantoso(2005) Good Corporate Culture sebagai inti dari Good Corporate Governance, Elex-Gramedia, Jakarta.

Nurlela, Rika dan Ishlahuddin. (2008) "Pengaruh Corporate Social Responsibility Terhadap Nilai Perusahaan dengan Prosentase Kepemilikan Manajemen sebagai Variabel Moderating". Simposium Nasional Akuntansi XI. Pontianak.

Oktavia dan Desmawati (2008) Pengaruh struktur kepemilikan, ukuran perusahaan, dan Struktur Dewan komisaris terhadap kinerja keuangan perusahaan public Sektor jasa" jurnal Akuntansi, Volume 8 no.1 67-68.

Rachmawati, Andri dan Triatmoko, Hanung, (2007) "Analisis Faktor-faktor yang Mempengaruhi Kualitas Laba dan Nilai Perusahaan”, Simposium Nasional Akuntansi 10, Makasar

Sujono dan Seobiantoro, Ugy (2007) Pengaruh Struktur Kepemilikan Saham, leverage,Faktor Intern dan Faktor Ekstern terhadap Nilai Perusahaan.

Shleifer,A. and R.W Vishny (1997) A Survey of corporate Governance . The Journal of Finance,LII (2) : 737-783

Sukma Swastika (2013) Analisis Pengaruh Struktur kepemilikan dan penerapan good corporate Governace terhadap nilai perusahaan pada sektor non keuangan yangterdaftar dibursa efek Indonesia.

Suad Husnan (2000) Corporate Governance di Indonesia: Pengamatan terhadap Sektor Corporate dan keuangan. Program magister hukum. UGM yogyakarta,2000.

Sulistyanto, Sri H. (2008). Manajemen Laba: Teori dan Model Empiris. Jakarta: Grasindo

Sawir, Agnes. (2004). Kebijakan Pendanaan dan Restrukturisasi Perusahaan. Jakarta; PT. Gramedia Pustaka Utama.

Sujoko dan Ugy Subiantoro. (2007). "Pengaruh Struktur Kepemilikan Saham, Leverage, Faktor Intern dan Faktor Ekstern Terhadap Nilai Perusahaan".Jurnal Manajemen dan Kewirausahaan, Volume 9, No.1, h.41-48.

Siagian, F., Siregar, S.V. and Rahadian, Y. (2013), "Corporate governance, reporting quality, and firm value: evidence from Indonesia", Journal of Accounting inEmerging Economie, Vol. 3 No. 1, pp. 4-20.

Shleifer, A. and R. W. Vishny, (1997), "A Survey of Corporate Governance.” The Journal of Finance, LII (2); 737-783.

Tandelilin, E .(2010) Portofolio dan Investasi: Teori dan Aplikasi. Yogyakarta. Kanisius

Tcvetkov M., Tcvetkova I. and Chkalova O (2015) Transaction Costs under Globalization: The Example of Russian Economy. European Research Studies Journal, 18(2), 107- 116.

Tri Gunarsih (2001). Corporate Governance: Struktur Kepemilikan, Kinerja dan Diversifikasi. 
Rancangan Proposal Disertasi.UGM,Yogyakarta

Tampubolon, Hery Bangun Kristiadi. (2012). "Pengaruh Pengungkapan CSR, GCG, Beban dan Pendapatan Terhadap Nilai Perusahaan Dengan Profitabilitas Sebagai Variabel Moderating Pada Perusahaan Perbankan Yang Terdaftar di BEI".Tesis. Universitas Sumatera Utara.

Utama, C.A. and Utama, S. (2009) Stock price reactions to announcements of related party transactions. Asian Journal of Business and Accounting 2(1-2): 1-23.

Utama, C.A. and Utama, S. (2012) Determinants of disclosure level of related party transactions in Indonesia. International Journal of Disclosure and Governance 2: 1-25.

Wahyuningsih, Eni K. Dan Hadinugroho, Bambang. (2004). Pengaruh Kinerja Keuangan Terhadap Harga Saham. Fokus Manajerial, Vol.2, No. 1.

Wahyudi, Darmawati dan Wibowo. (2005) Implikasi Struktur Kepemilikan Terhadap Nilai Perusahaan : Dengan Keputusan Keuangan Sebagai Variabel Intervening. Makalah disampaikan pada Simposium Nasional Akuntansi IX, 23-26 Agustus

Wahyudi, Untung dan Hartini Pawestri. 2006. Implikasi Struktur Kepemilikan Terhadap Nilai Perusahaan: Dengan Keputusan Keuangan Sebagai Variabel Intervening. Simposium Nasional Akuntansi (SNA) IX Padang.

Wahyudi, Untung dan Pawestri, Hartini Prasetyaning, 2006, "Implikasi Struktur Kepemilikan Terhadap Nilai Perusahaan:Dengan Keputusan Keuangan Sebagai Variabel Intervening", Simposium Nasional Akuntansi Padang, 2326 Agustus 2006.Universitas Widyagama Malang.

Yermack, D. (1996). Higher Market Valuation of Companies with Small Board of Directors. Journal of Financial Economics. 40, 185-211. 